\title{
INVESTIGATION OF TEMPORAL CHANGE OF LAND USE IN ELMALI BASIN USING REMOTE SENSING AND GEOGRAPHIC INFORMATION SYSTEMS
}

\author{
H. MENTEŞE ${ }^{1}$, A. EYMEN ${ }^{2}$ * \\ ${ }^{1}$ Graduate School of Natural and Applied Sciences, Geomatic Engineering, Erciyes University, Kayseri, Turkey - \\ htcmnts46@gmail.com \\ ${ }^{2}$ Engineering Faculty, Geomatic Engineering, Erciyes University, Kayseri, Turkey - ageymen@erciyes.edu.tr
}

KEY WORDS: Land Use, Elmalı Basin, Geographic Information Systems, Remote Sensing.

\begin{abstract}
:
The sustainable use of water and soil, which are indispensable for living things, is closely related to the concept of land use. While land use is becoming gradually modern as a necessity of the age, urbanization and industrialization are also gaining great importance. So much so that, in Turkey, where agriculture-based economy was emphasized until the 1980s, interest in exports of industrial products has increased in recent years and industrial investments especially in the Marmara region have increased considerably. This situation has increased job opportunities due to the industrialization developing in the region and has led to an increase in the population in parallel. The structure process has accelerated in order to meet the needs of the increasing population.
\end{abstract}

Basin areas, which contain a wide variety of classes, are among the regions that are highly affected by these changes. Within the scope of the study, Elmalı Basin, which is used to supply potable and utility water to the province of Istanbul, was chosen as the study area. Within the scope of the research, the temporal change of the land use in Elmalı Basin has been investigated by using Landsat-8 satellite with a spatial resolution of 30 meters for the years 2013, 2015, 2018 and 2020 taking advantage of Geographical Information Systems (GIS) and Remote Sensing (RS) technologies. Classification was made with support vector machines, one of the controlled classification methods on satellite images, and the changes in land use were evaluated by comparing the images of working years.

\section{INTRODUCTION}

Human beings actively use many riches that exist throughout their lives. It is seen that among these riches, land use comes to the fore (Sarı and Özşahin, 2016). As a requirement of the age we live in, land uses have become increasingly modern, as well as urbanization and industrialization have gained importance. Many negative situations have emerged with urbanization and industrialization, and changes that are contrary to natural use cause the traces of climate change to increase (Özdemir, 2015). Therefore it is increasing interest in the problems arising from the abuse of land use and land (Elmastaş, 2008).

Each of the basins has its own natural (wild life, geological, vegetation, geomorphological, climate and hydrological), sociocultural and economic (transportation, infrastructure, administrative structure, land use, population) characteristics (Tan1k, 2017). Basin areas, which contain complex layers such as settlement area, water area, forest, land areas, mine and quarry areas, agriculture/pasture area, industrial area, park and access roads, are among the main regions that should be used carefully and planned in terms of land use activities (Garipağaoğlu, 2012).

Geographic information systems are an information system that is created by location-based observations according to the requirements of the institution it is associated with, provides the collection, storage and analysis of graphic and attribute data, and contains more than one data type (Yomralıoglu, 2000; Uluğtekin and Bildirici, 1997). At the same time, it provides images in maps and 3D environments and presents these results to the user. Remote sensing provides a great advantage to the user as it monitors and measures large areas at once, achieves faster output and does not require much labor (Çakaroz et al, 2020). At the same time, the data recorded in remote sensing forms an important data base for GIS (Gözükara et al, 2015).

It is not possible to detect mistakes made in land use before determining the current state of the land situation (Ilgar and Koca, 2006; Yüksek, 2018). In addition to this, it will be an important step to establish a road map by determining the temporal changes in land use in the past, in order to reverse the mistakes made (Dengiz and Demirağ Turan, 2014). When the changes that the land has undergone are investigated and examined for their reasons, the accuracy of the study will increase and it will provide a suitable use for the structure of the land (Yüksek, 2018).

In the studies carried out in this direction, it has been emphasized that the basins are affected by the constructions that occur due to the increasing population in the city (Geymen, 2013; Geymen, 2017). This study was carried out to determine the changes in the land use of the Elmalı basin over the years. In line with the results obtained, it is likely to be an important guide to the arrangements and practices planned for the study area in the future. The planning of land use will form an important base for the changes in time and even for the protection of natural resources.

The subject of this study has been determined as the temporal change of land use of Elmalı Basin, which produces drinking water for the people of Istanbul, with the help of satellite images using Geographical Information Systems and Remote Sensing methods. Using satellite images is important because it

\footnotetext{
* Corresponding author
} 
can cover larger areas and save time (Çağlak and Özelkan, 2019).

\section{METHOD AND MATERIAL}

Within the scope of the study, satellite images of the relevant years were obtained from the USGS website for the determination of land use change. Afterwards, these satellite images were subjected to processes such as band fusion, image classification and accuracy analysis in ENVI Classic 5.3 software. Finally, the necessary spatial analysis and queries and final products were obtained from the layers related to land use obtained in ArcGIS 10.4 software.

It was preferred to use the satellite images of Landsat-8 2013, 2015, 2018 and 2020 of the Elmal Basin. Among the reasons for this; It is low in cost, remains up-to-date because it can be obtained quickly, and images can be displayed as covering very large areas (Erbay, 2005). Since almost all satellite images are digital and contain location information, it forms a basis for analysis and queries for GIS and for almost every study in remote sensing (Erbay, 2005; Geymen, 2016; Siart et al, 2009).

Figure1. shows the Landsat- 8 satellite images of the years 2013, 2015, 2018 and 2020 used in the study.

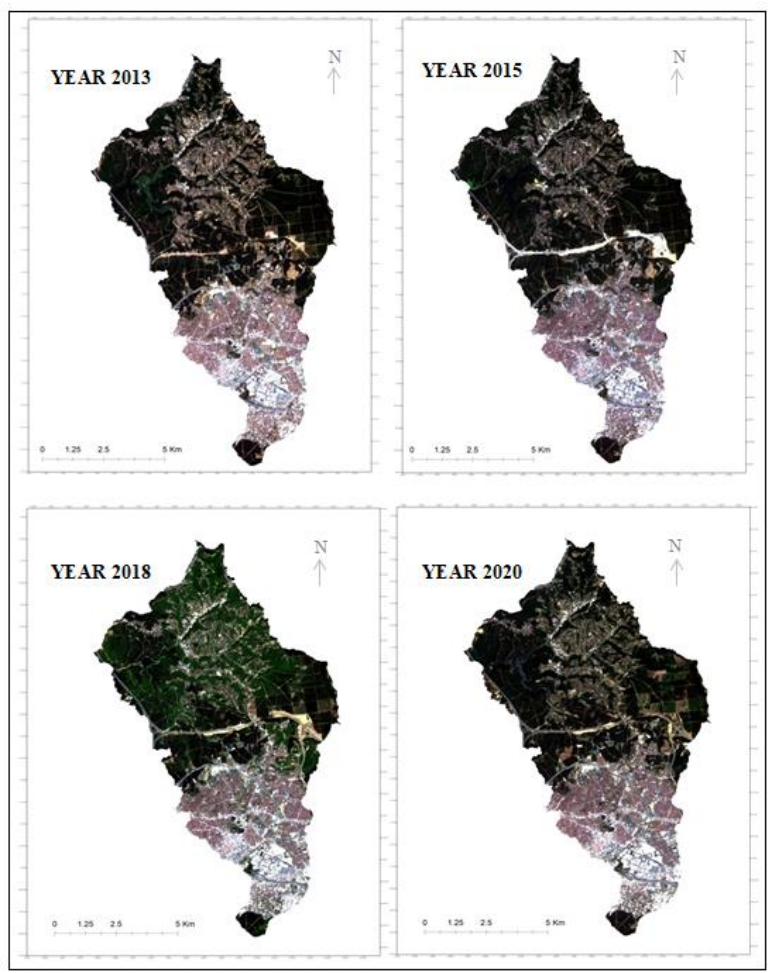

Figure 1. Landsat-8 Satellite Images Used in the Study

The Landsat-8 satellite was developed as a collaboration between NASA and the US Geological Survey (USGS) and was launched in California on February 11, 2013 (URL 1). The payload of the Landsat- 8 satellite consists of two instruments, the Operational Terrain Imager (OLI) and the Thermal Infrared Sensor (TIRS) (URL 12). The satellite's radiometric resolution is 8 bits and the strip width is $185 \mathrm{~km}$ (Kurnaz, 2019).

\subsection{Method Followed}

The method followed in the study is given in Figure 2.

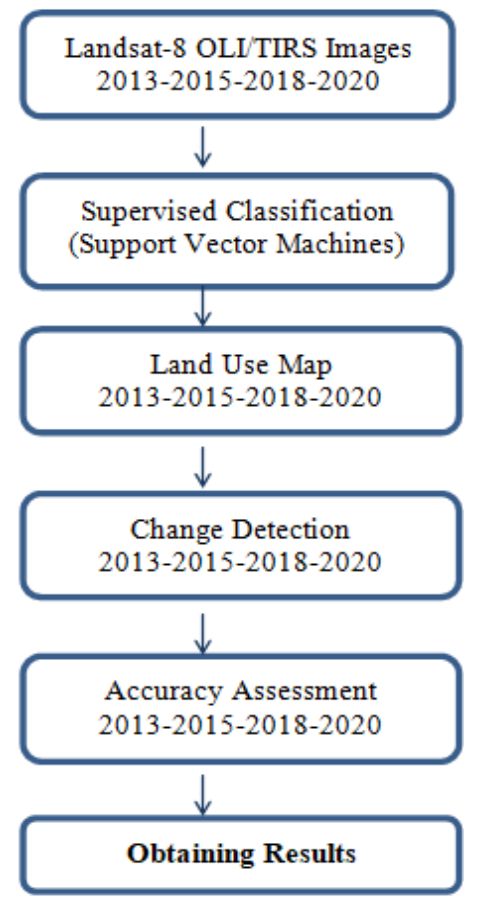

Figure 2. Workflow Diagram

\subsection{Study Area}

The Elmalı Basin, chosen as the study area, is located within the borders of the Istanbul province of the Marmara region and on the Anatolian side of the province (Geymen, 2017). The total area of the basin includes the settlements of Ümraniye and Ataşehir on the west, Sancaktepe and Çekmeköy on the east, Maltepe on the south and Beykoz on the north (Özonat, 2017).

Figure 3. shows the study area.

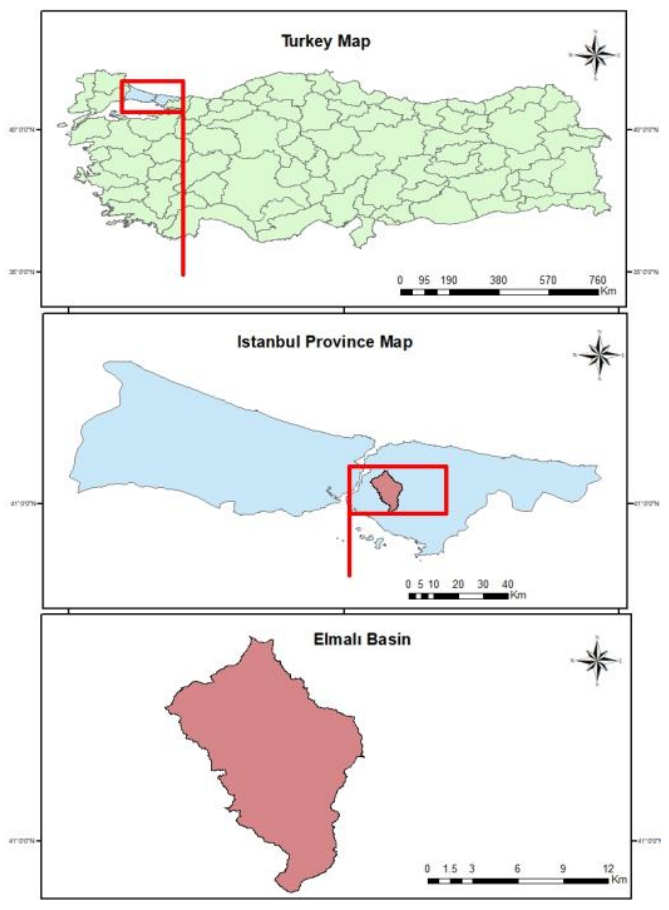

Figure 3. Study Area 
Elmalı dam in the basin area consists of two parts. The construction of the first of these was completed between 18911893 (Gurbetoğlu, 1996). The second Elmalı Dam was started to be built on Çavuşbaş1 Stream in 1952 and was completed in 1955 (Özonat, 2017).

\section{RESULTS}

\subsection{Land Uses Maps And Change Detection}

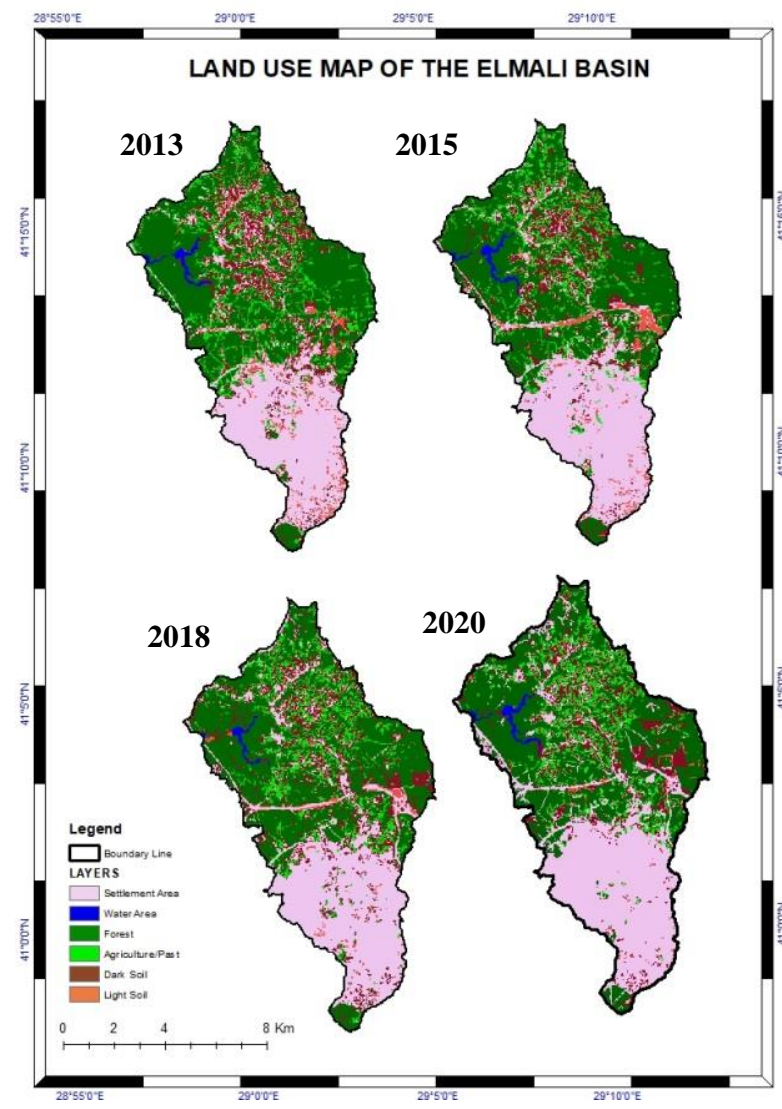

Figure 4. Land Use Maps of Working Years

As can be seen in Figure 4., the beginning of the construction of the previously planned structures from 2013 to 2020 , the transportation roads completed in this period, the organized industrial zone in the basin area and the newly created structures caused the settlement area to increase. However, considering the increasing population due to the job opportunities they provide and the urbanization situation that comes with it, it is inevitable to see an increase in settlement areas.

Considering the land use status of the study area, it is seen that the forest area contains a large amount of area compared to other classes due to the dense forest area around the water area of the basin. Despite this, it has become a remarkable point that the southern parts of the city create quite a lot of residential areas.

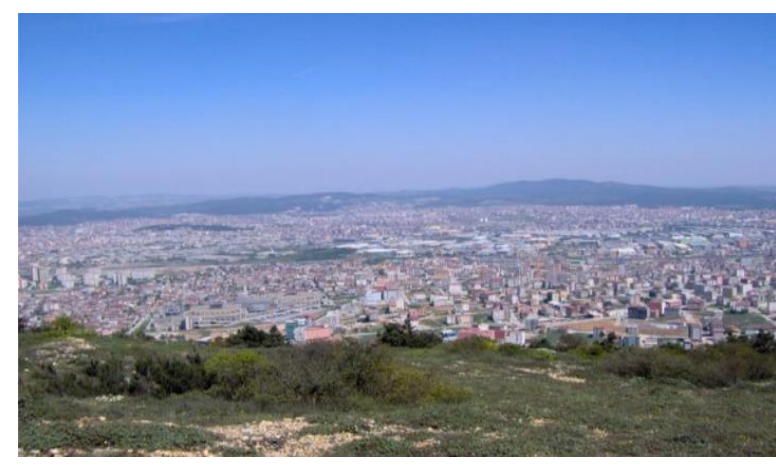

Figure 5. Settlement Area of Elmalı Basin (Geymen, 2016)

Table 1. the land use cases for 2013, 2015, 2018 and 2020 are given. As can be seen in Table 1., the settlement area, which was 2528.01 hectares in 2013, increased to 3026.70 hectares in 2020. While the water area was 61.65 hectares in 2013, it decreased to 39.24 hectares in 2018 and then increased. While the forest area was 3300.39 hectares in 2013 , it decreased to 3170.25 hectares in 2020 and showed a continuous decrease over the years. Likewise, the agricultural/pasture area, which was 939.51 hectares in 2013 , decreased to 931.32 hectares in 2020. The dark soil area, which was 1222.38 hectares in 2013 , decreased to 1072.71 hectares by 2020 . Similarly, the light soil area, which was 296.01 hectares in 2013, decreased gradually until 2020.

\begin{tabular}{|c|c|c|c|c|}
\hline & \multicolumn{2}{|c|}{ YEAR 2013 } & \multicolumn{2}{c|}{ YEAR 2015 } \\
\hline CLASS & hectar & \% & hectar & \% \\
\hline Settlement Area & 2528.01 & 30.28 & 2662.20 & 31.89 \\
\hline Water Area & 61.65 & 0.74 & 70.47 & 0.84 \\
\hline Forest & 3300.39 & 39.54 & 3297.33 & 39.50 \\
\hline Agriculture/Pasture & 939.51 & 11.25 & 937.17 & 11.23 \\
\hline Dark Soil & 1222.38 & 14.64 & 1105.83 & 13.25 \\
\hline Light Soil & 296.01 & 3.55 & 274.95 & 3.29 \\
\hline TOTAL & 8347.95 & 100 & 8347.95 & 100 \\
\hline & YEAR 2018 & YEAR 2020 \\
\hline CLASS & hectar & \% & hectar & \% \\
\hline Settlement Area & 2723.13 & 32.62 & 3026.70 & 36.26 \\
\hline Water Area & 39.24 & 0.47 & 66.60 & 0.80 \\
\hline Forest & 3172.77 & 38.01 & 3170.25 & 37.98 \\
\hline Agriculture/Pasture & 932.94 & 11.18 & 931.32 & 11.16 \\
\hline Dark Soil & 1340.37 & 16.06 & 1072.71 & 12.85 \\
\hline Light Soil & 139.5 & 1.67 & 80.37 & 0.96 \\
\hline TOTAL & 8347.95 & 100 & 8347.95 & 100 \\
\hline
\end{tabular}

Table 1. Land Use Status of Working Years

\begin{tabular}{|l|c|c|c|c|}
\hline Values/Years & $\mathbf{2 0 1 3}$ & $\mathbf{2 0 1 5}$ & $\mathbf{2 0 1 8}$ & $\mathbf{2 0 2 0}$ \\
\hline $\begin{array}{l}\text { Overall } \\
\text { Accuracy }\end{array}$ & $96.32 \%$ & $97.70 \%$ & $95.87 \%$ & $98.16 \%$ \\
\hline $\begin{array}{l}\text { Kappa } \\
\text { Coefficient }\end{array}$ & 0.94 & 0.97 & 0.94 & 0.97 \\
\hline
\end{tabular}

Table 2. Elmalı Basin Classification Accuracy Results 
Kappa coefficient, which was formed from error matrices, was used in the accuracy evaluation stage, where the accuracy of the classification was examined (Çetinkaya and Toz, 2007). Kappa value takes a value between 0 and 1 , and it is desirable for the Kappa value to be 1 (Çetinkaya and Toz, 2007). Applications where the Kappa coefficient exceeds 0.75 and the overall accuracy rate exceeds $80 \%$ are considered reliable (Kaya and Toroğlu, 2015).
Table 2. shows the overall accuracy and kappa value. Kappa value for 2013, 0.94; the 2015 kappa value for 0.97 ; the 2018 kappa value for 0.94 , the 2020 kappa value for 0.97 , and the values are quite successful. Considering these values, it is concluded that the support vector machines method used in the controlled classification of the working years has reached a high level of accuracy.

\section{CONCLUSION}

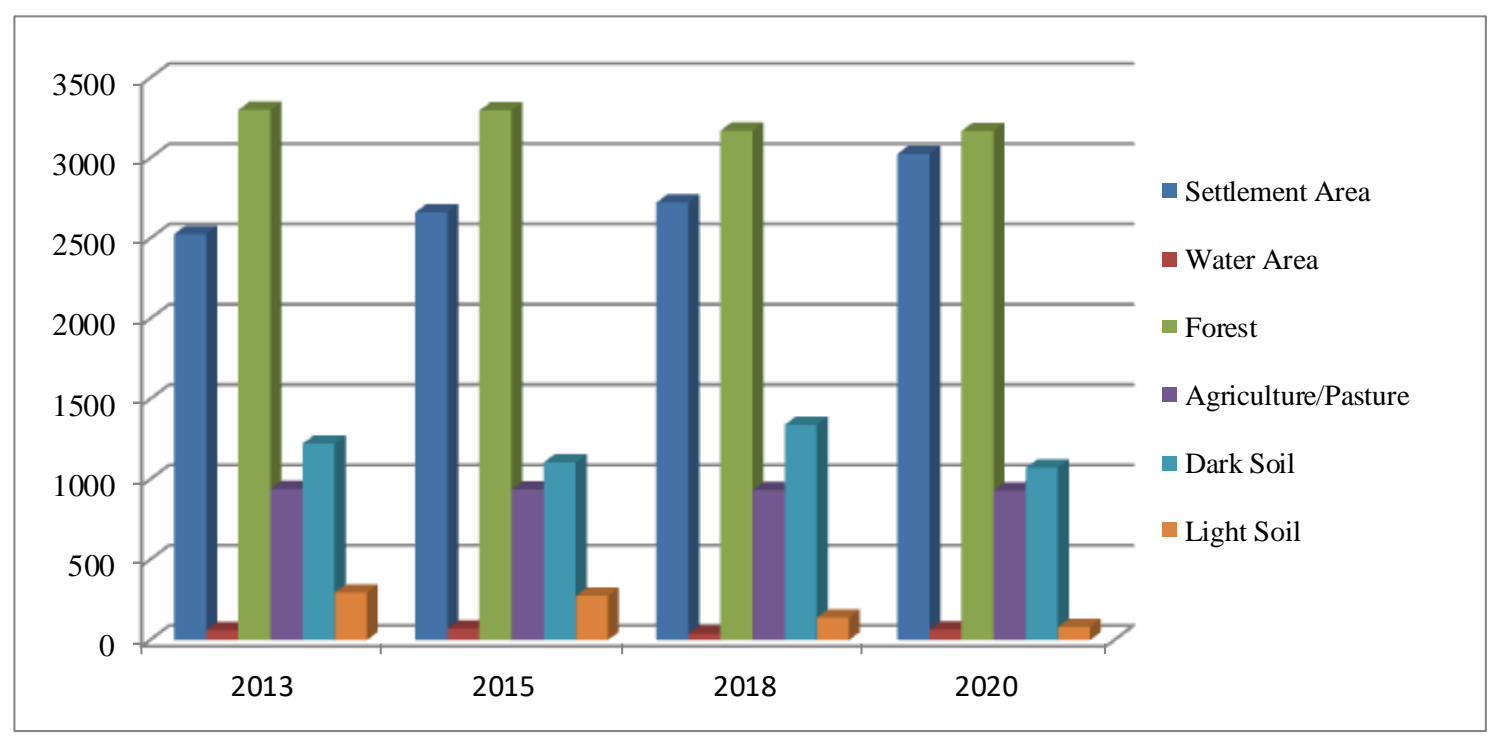

Figure 6. Land Use Chart for Working Years

In line with the data in Figure 4. and Table 1., it is seen that the settlement area, which was at its lowest level in 2013, increased in 2015 and 2018 and approached the forest area in 2020. As a result of the data obtained in Figure 4. and Table1., it has been interpreted that forest, agriculture/pasture and light soil areas have decreased over the years, and that the dark soil area has changed depending on the land use.

Figure 6. shows the graph created to compare the land uses of the working years.

According to the information given in the study, the settlement area in 2013 increased by approximately 5\% to form the settlement area in 2015, and the settlement area in 2013 increased by approximately $20 \%$ to form the settlement area in 2020. Although there was an increase of almost $14 \%$ in the water area from 2013 to 2015 , there was a decrease of $44 \%$ from 2015 to 2018. According to the data obtained for each year included in the study, the forest area decreased from year to year. It also decreased by almost 4\% from 2013 to 2020 . Likewise, the agricultural/pasture area has decreased over the years, with a decrease of approximately $0.9 \%$ in 2020 compared to 2013 .

Considering the dark soil class, although it increased by $21 \%$ from 2015 to 2018 , there was a $12 \%$ decrease from 2013 to 2020. It has been commented that the reason for this change may be due to the confusion with the agricultural/pasture area in some areas and due to the ongoing works. If we take a look at the light soil class, it decreased gradually compared to the previous year and showed a decrease of approximately $73 \%$ in

2020 compared to 2013, which is the most striking value in the table. The perception of the transportation roads under construction as light soil from the satellite image and the progress of the road works in the following years explain the reason for this situation.

It is seen that the settlement areas have increased gradually during the working years and the areas such as forest, agriculture/pasture have decreased. Such problems are caused by many reasons such as uncontrolled changes in land use, use of fertile lands in various structural activities without making the necessary distinction instead of agricultural/pasture areas that have lost their function. In addition, the destruction of forest and agricultural/pasture areas in order to open settlements and access roads are among the reasons.

In order to leave a sustainable environment for the future, attention should be paid to land use activities in basin areas and action should be taken in line with land use classes.

Although Elmalı Basin has smaller water storage area compared to other basins in the province where it is located, it is seen that it has the highest density in terms of population and a large amount of settlement area (Kaya, 2008; Özonat, 2017; Budak and Tüzün, 1993). Accordingly, the unplanned construction in the region and the high level of pollution of the streams that bring water to the basin also affect the pollution rate of the basin waters (Şenol, 2012). The main reason for the changes in 
land use, especially the decrease in forest and agricultural/pasture areas, is of course the uncontrollability of construction at some points. Because people need single or multi-storey buildings to work and live. In order to meet these needs, they feel a sense of migration to places with a large workforce and put this into action. While the population factor contributes to the development of the region and the preservation of its urban vitality, it also brings with it negativities. A branch of the Istanbul ring road connecting to the Fatih Sultan Mehmet Bridge passes through the basin area, at the same time, there is the Dudullu Organized Industrial Zone in the region and there are many structures such as the ÜsküdarÜmraniye-Çekmeköy Metro Line Segment Factory and Warehouse Area. Therefore, the area has moved away from its rural features.

Remote Sensing and Geographic Information Systems technologies, which are very beneficial in terms of cost and time, should be used effectively and efficiently by considering the basin area as a whole. Care should be taken to work multidisciplinary, as the basin areas are composed of a wide variety of ecosystems. By taking the opinions of different disciplines, the most correct joint decisions should be formed for the basin area.

In order to prevent floods, strengthen groundwater and increase soil permeability, it would be beneficial to use concrete and asphalt with high absorption power in order to leave a sustainable basin area, although it is costly, and to regulate atmospheric relations. It is thought that when the site gardens, parking areas, sidewalks and roads are formed with this permeable material, the damages of concretization will be alleviated to some extent.

Finally, the Elmalı basin, which was studied as a result of the findings obtained from the spatial analyzes prepared by using the Landsat- 8 satellite images of the years 2013, 2015, 2018 and 2020, should be used according to the skill classes, taking into account the natural environment conditions. Of course, this also applies to other basin areas. Citizens should be made aware of this issue. For a sustainable basin area, studies should be carried out with relevant public institutions and organizations, as well as non-governmental organizations, and new generation breakthroughs should be made in land use and basin area use planning.

\section{REFERENCES}

Budak, S., Tüzün, G., 1993: Istanbul's drinking water basins. Journal of Planlama Sci., pp.46-51.

Çağlak, E., Özelkan, E., 2019. Using Satellite Remote Sensing in Collecting Reliable News. Journal of Social Sciences of Anemon Mus Alparslan University, 7(4): 83-91.

Çakaroz, D., Özelkan E., Karaman, M., 2020. Investigation of the effect of drought on temporal change in wetlands determined by Remote Sensing: The case study in Umurbey Delta (Çanakkale). European Journal of Science and Technology, (20): 898-916.

Çetinkaya, B., Toz, G., 2007. Usage of error matrix in the accuracy assessment of geographic data selection results. Journal of Istanbul Technical University /D Engineering 6(56): 59-68.
Dengiz, O., Demirağ Turan, İ., 2014. Determination of temporal change land use / land cover using remote sensing and geographic information system techniques the central district of Samsun (1984-2011). Turk J Agric Res 1: 78-90 TÜTAD ISSN: 2148-2306.

Elmastaş, N., 2008. Land use in the Kahta river basin. Turkish Journal of Geographical Sciences, 6 (2):159-190.

Erbay, A. Y., 2005. Satellite Images Guide Booklet. Nik Construction Trade Ltd. Sti., Istanbul. (Web page: Https://Abs.Cu.Edu.Tr/Dokumanlar/2015/Css119/732746616_ Uydu_Goruntuleri_Rehber_Kitapcigi.Pdf )

Garipağaoğlu, N., 2012. The role of geography in reservoir planning and the reservoir planning in Turkey. Journal of Atatürk University Social Sciences Institute, 16 (2): 303-337.

Geymen A., 2013. Impacts of bosporus bridges on the Istanbul metropolitan settlement areas. Land Degradation \& Development, 24(2): 156-169.

Geymen, A., 2016. Monitoring of natural resources in water basin using geographical information systems: Elmalı basin case study. KSU J. Nat. Sci., 19(2), 174-180.

Geymen, A., 2017. Monitoring of environmental impacts and land-use changes in water basin using geographical information systems: Elmalı basin case study. Iğdır Univ. J. Inst. Sci. \& Tech., 7 (1): 171-181.

Gözükara, G., Altunbaş, S., Sarı, M., 2015. Monıtorıng of organic farming fields with the a1d of remote sensing and geographic information systems, pp.156-165. Eastern Black Sea II. Organic Agriculture Congress, 6-9 October 2015, Pazar/ Rize, Recep Tayyip Erdoğan University Faculty of Agriculture and Natural Sciences, p. 692.

Gurbetoğlu, S., 1996. A research of settlements located in the reservoir of Elmalı dam from the aspect of environmental policy. Istanbul University Institute of Science and Technology, Master Thesis, Istanbul, pp.37.

Ilgar, R., Koca, N. 2006. Potential of ecological transportation on coastal water in water management. Electronic Journal of Social Sciences, 5 (16): 122-134.

Kaya, C., 2008. Investigation Of Surface And Underground Water Pollution In The North Region Of Elmali Basin. İstanbul Technical University Institute of Science and Technology, Thesis (M.Sc.), İstanbul, pp.139.

Kaya, Ö., Toroğlu, E., 2015. Monitoring urban development of Kayseri and change detection analysis. Turkish Journal of Geography (65): 87-96.

Kurnaz, B., 2019. Determination of forest fire area by using landsat- 8 and sentınel-2 satellite 1mages: Muğla case. Zonguldak Bülent Ecevit University Graduate School of Natural and Applied Sciences Department of Geomatics Engineering, M. Sc. Thesis, Zonguldak, pp.77.

Özdemir, H. Y., 2015. Determination of land use change in Hasanlar dam basin. Duzce University Graduate School of Natural and Applied Sciences, Departmant of Forest Engineering, Master of Science Thesis, Düzce, pp.90. 
Özonat, Ç., 2017. Evaluation of the Effects of Land Use Changes on Drinking Water Basins: The Case of Elmalı Dam Lake Basin. T. C. Ministry of Forestry and Water Affairs, Specialization Thesis, Ankara, pp.144.

Sarı, H., Özşahin, E., 2016. Analysis of LULC (Landuse/Landcover) characteristics of Tekirdag province based on the CORINE System. Alinteri Journal of Agricultural Sciences, 30 (B): $13-26$.

Siart, C., Bubenzer, O., \& Eitel, B., 2009. Combining digital elevation data (SRTM/ASTER), high resolution satellite imagery (Quickbird) and GIS for geomorphological mapping: A multi-component case study on Mediterranean karst in Central Crete. Geomorphology, 112(1-2): 106-121.

Şenol, C., 2012. Ecological problems of Istanbul's drınkıng water basins, pp.373-382. III. National Geomorphology Symposium, Hatay, Turkey.

Tan1k, A., 2017. Integrated watershed management issues and approaches, Watershed Planning and Management Symposium, 20-22 December 2017, Bursa

Uluğtekin, N., Bildirici, Ö., 1997. Geographic information system and map, pp:85-95. 6th Map Congress Proceedings Book, Ankara.

URL 1: https://landsat.gsfc.nasa.gov/landsat-8/landsat-8overview Date of access: 03.05.2021

Yomralığlu, T., 2000. Geographic Information Systems Basic Concepts and Applications. Trabzon: Karadeniz Technical University, Department of Geodesy and Photogrammetry Engineering, Istanbul, pp.480.

Yüksek, İ., 2018. Temporal change of land use: example of Karasu river basin in the years of (1985-2015). Harran University, Institute of Social Sciences Department of Geography, Master's Thesis, Şanlıurfa, pp.138. 